\title{
Безпека та ефективність симультанних лапароскопічних втручань при лікуванні жовчнокам'яної хвороби та поеднаної хірургічної патології органів черевної порожнини
}

\begin{abstract}
Мета роботи: дослідити вплив симультанних лапароскопічних операцій на фізичний стан післяопераційного хворого.
Матеріали і методи. У роботі представлено статистичні дані щодо лікування 411 хворих із жовчнокам’яною хворобою (ЖКХ) та супутньою хірургічною патологією. Для оцінки використовували чіткі числові показники: тривалість операції, об’єм крововтрати, рівень глікемії, рівень кортизолу та альдостерону, сатурація кисню крові, рівень гемоглобіну, креатиніну. Оцінку здійснювали за допомогою шкал Leе та ARISCAT. Отримані результати вносили в базу даних Microsoft Office Excel 2010, oпис кількісних ознак - на основі критерію Шапіро-Уілка з визначенням середнього арифметинчного (М) і стандартного відхилення (S). Для порівняння груп використовували критерії Манна-Уїтні, або U-критерій. При широкому порівнянні використовували метод ANOVA. Критичний рівень значущості р у всіх розрахунках визначено як 0,05.

Результати досліджень та їх обговорення. При обробці даних виявлено збільшення часу операційного втручання. Загалом

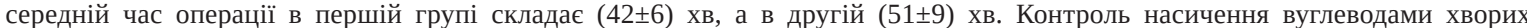
достатньо мірою допоміг запобігти суб’єктивному дискомфорту, а рівень глікемії лабараторно не відрізнявся і не потребував корекції інсуліном. За критерій розвитку артеріальної гіпотензії прийнято зниження середнього артеріального тиску на 30 \% від початкового або нижче 80 мм рт. ст. у систолічній фазі або девіацією сегмента ST на ЕКГ.
\end{abstract}

Ключові слова: хірургія; холецистектомія; жовчнокам’яна хвороба; лапароскопія; симультанні втручання; стрес.

Постановка проблеми і аналіз останніх досліджень та публікацій. Внаслідок жовчнокам'яної хвороби (ЖКХ) страждає до 30 \% дорослого населення землі. Статистика свідчить, що до 20 \% хворих у США мають вже діагностовану ЖКХ, ще 1-3 \% діагностують нові випадки щороку, у 500000 хворих розвиваються ускладнення ЖКХ, що стає причиною до 10000 смертей, з яких до 7000 - це прямі ускладнення гострого холециститу і холедохолітіазу [2-4, 10]. В Європі епідеміологія подібна з щорічною ранньою діагностикою 1,39 хворих на 100000 обстежених [5-7, 15]. Жінки хворіють в 3 рази частіше. Після 55 років до 68,6 \% жінок і до 22,4 \% чоловіків мають конкременти жовчного міхура. Значне поширення і небезпечні ускладнення роблять дослідження із лікування даної патології актуальними. Завдяки малоінвазивним методам, сучасним технікам і протоколам ERAS хірургічне операційне лікування не лише безпечне і легко переноситься хворими, а й пріоритетним над консервативною курацією пацієнта [1].

Часто ЖКХ поєднана з іншою хірургічною патологією (до 22 \% хворих на ЖКХ). У 74 \% випадків дана патологія в межах черевної порожнини, 1015 \% страждають від холедохолітіазу в поєднанні із холецистолітіазом [1]. Тому в останні роки із розвитком лапароскопічної технології суттєво розвинулись техніки симультанного операційного лікування.

Під час операції організм зазнає серйозний травматичний та ноцицептивний стрес, внаслі- док чого виділяється велика кількість медіаторі запалення, основним з яких для розвитку стресвідповіді є ІЛ-6. У відповідь на це відбувається значний викид стрес-гормонів: АКТГ, альдостерон, кортизол, глюкагон, адреналін. Це допомагає організму стійко переносити зовнішні втручання та гарантувати йому видужання. Спочатку компенсаторний механізм зі збільшенням тривалості операції набуває патологічного, деструктивного характеру й провокує основні метаболічні, нейроендокринні і запальні зміни, що призводять до післяопераційної дисфункції органів і системи $[8,11]$, і є основною причиною післяопераційної летальності $[9,12,14]$. Корекція цих показників і зменшення травматизації і часу операції знижує рівень хірургічної стрес-відповіді і допомагає запобігти ускладненням при одночасному пришвидшенні видужання [13].

Мета роботи: кількісно визначити та оцінити вплив на організм пацієнта симультанних лапароскопічних оперецій, оцінити ризик для здоров'я пацієнта таких операцій. Відповідно до отриманих результатів визначити доцільність використання технології симультанних операцій для лікування хворих на жовчнокам'яну хворобу та супутню хірургічну патологію.

Матеріали і методи. На базі Волинської обласної клінічної лікарні у відділенні інвазивних методів діагностики та лікування (ВОКЛ ВІМДЛ) вико- 
нано 411 симультанних лапароскопічних операційних втручань з метою лікування ЖКХ та супутньої хірургічної патології органів черевної порожнини. В усіх випадках хворим виконували лапароскопічну холецистектомію. Доступ виконували згідно 3 розробленими на базі Волинської обласної клініч- ної лікарні у відділенні інвазивних методів діагностики та лікування, рекомендації із встановлення портів і ергономіки операції (табл. 1).

Найчастіше хворіють жінки віком 45-60 років з операційним ризиком за ASA 2 і 1 супутньою патологією (табл. 2-5).

Таблиця 1. Характер симультанних лапароскопічних операційних втручань

\begin{tabular}{|c|c|c|}
\hline "Назва операційного втручання & К Кількість номінальна & Відсоток \\
\hline ЛХЕ+ЛКР фундоплікація за Тупе & 87 & 21,17 \\
\hline ЛХЕ+ТАРР & 15 & 3,65 \\
\hline ЛХЕ+пластика вентральної кили & 5 & 1,22 \\
\hline ЛХЕ+пластика пупкової кили & 1 & 0,24 \\
\hline ЛХЕ+вертикальна резекція шлунка & 1 & 0,24 \\
\hline ЛХЕ+геміколектомія & 4 & 0,97 \\
\hline ЛХЕ+адреналектомія & 5 & 1,22 \\
\hline ЛХЕ+новоутворення печінки (доброякісні) & 39 & 9,49 \\
\hline ЛХЕ+новоутворення підшлункової залози (доброякісні) & 11 & 2,68 \\
\hline ЛХЕ+адгезіолізис & 36 & 8,76 \\
\hline ЛХЕ+холедохолітотомія & 118 & 28,71 \\
\hline ЛХЕ+інтраопераційна холангіографія & 89 & 21,65 \\
\hline Загалом & 411 & 100 \\
\hline
\end{tabular}

Таблиця 2. Характер операційних втручань за віком і статтю

\begin{tabular}{|c|c|c|c|c|c|c|c|c|}
\hline \multirow{4}{*}{ Назви операційних втручань } & \multicolumn{8}{|c|}{ Вік, роки } \\
\hline & \multicolumn{2}{|c|}{$25-44$} & \multicolumn{2}{|c|}{$45-60$} & \multicolumn{2}{|c|}{$60-75$} & \multicolumn{2}{|c|}{$75-90$} \\
\hline & \multicolumn{8}{|c|}{ Стать } \\
\hline & $Ч$ & Ж & $\Psi$ & Ж & Ч & Ж & 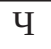 & Ж \\
\hline ЛХЕ+ЛКР фундоплікація за Тупе & 6 & 6 & 11 & 32 & 4 & 25 & 1 & 2 \\
\hline ЛХЕ+ТАРР & 0 & 1 & 4 & 7 & 3 & 0 & 0 & 0 \\
\hline ЛХЕ+пластика вентральної кили & 1 & 1 & 0 & 0 & 1 & 2 & 0 & 0 \\
\hline ЛХЕ+пластика пупкової кили & 0 & 0 & 0 & 0 & 0 & 1 & 0 & 0 \\
\hline ЛХЕ+вертикальна резекція шлунка & 0 & 1 & 0 & 0 & 0 & 0 & 0 & 0 \\
\hline ЛХЕ+геміколектомія & 1 & 1 & 1 & 1 & 0 & 0 & 0 & 0 \\
\hline ЛХЕ+адреналектомія & 0 & 1 & 0 & 2 & 0 & 2 & 0 & 0 \\
\hline ЛХЕ+новоутворення печінки (доброякісні) & 4 & 2 & 7 & 7 & 6 & 10 & 2 & 1 \\
\hline $\begin{array}{l}\text { ЛХЕ+новоутворення підшлункової залози } \\
\text { (доброякісні) }\end{array}$ & 0 & 4 & 3 & 2 & 0 & 0 & 1 & 1 \\
\hline ЛХЕ+адгезіолізис & 2 & 5 & 7 & 11 & 4 & 5 & 0 & 2 \\
\hline ЛХЕ+холедохолітотомія & 2 & 14 & 9 & 18 & 15 & 31 & 12 & 17 \\
\hline ЛХЕ+інтраопераційна холангіографія & 11 & 17 & 12 & 22 & 5 & 14 & 1 & 7 \\
\hline
\end{tabular}

Таблиця 3. Ризик операційних втручань

\begin{tabular}{|c|c|c||}
\hline Ступінь & Кількість & Відсоток \\
\hline 1 & 9 & 2,2 \\
\hline 2 & 341 & 83 \\
\hline 3 & 61 & 14,8 \\
\hline
\end{tabular}


Таблиця 4. Ризик операційних втручань за віком

\begin{tabular}{||c|c|c|c|c||}
\hline \hline \multirow{2}{*}{ Ступінь } & \multicolumn{4}{|c|}{ Вік, роки } \\
\cline { 2 - 5 } & $25-44$ & $44-60$ & $60-75$ & $75-90$ \\
\hline 1 & 4 & 5 & 0 & 0 \\
\hline 2 & 73 & 131 & 108 & 29 \\
\hline 3 & 3 & 20 & 20 & 18 \\
\hline
\end{tabular}

Таблиця 5. Об'єм операційних втручань за віком

\begin{tabular}{||c|c|c|c|c||}
\hline \multirow{2}{*}{ Вікові групи } & \multicolumn{4}{|c||}{ Об’єм операційних втручань } \\
\cline { 2 - 5 } & низький & середній & високий & розширений \\
\hline $25-44$ & 0 & 62 & 16 & 2 \\
\hline $44-60$ & 0 & 107 & 47 & 2 \\
\hline $60-75$ & 0 & 94 & 34 & 0 \\
\hline $75-90$ & 0 & 39 & 7 & 1 \\
\hline
\end{tabular}

Для точної об’єктивної оцінки ефективності симультанних операційних втручань ми порівнювали дві групи хворих - I група - хворі, яким виконали лише лікування однієї хірургічної патологіï, і II група - хворі, яким виконали симультанне лапароскопічне операційне лікування ЖКХ та супутньої хірургічної патології. Хворим I групи виконували лікування 3 проведенням операційного втручання за класичною методикою, а II групі - за власною методикою. Для оцінки в нашому досліді використовували такі чіткі числові показники, як тривалість операції в хвилинах, об’єм крововтрати, рівень глікемії, рівень кортизолу та альдостерону, сатурація кисню крові, рівень гемоглобіну, креатиніну. Показники застосовували для визначення рівня хірургічної стрес-відповіді, а також для оцінки кардіологічної періопераційної захворюваності у хворих, які отримують не кардіоваскулярне операційне лікування, а також показники ризику респіраторних ускладнень у хворих у післяопераційному періоді. Рівень хірургічної стресвідповіді перегукується з деякими аспектами шкал Lee та ARISCAT. Отримані результати вносили до бази даних Microsoft Office Excel 2010 (Microsoft Corp, США), опис кількісних ознак, на основі критерію Шапіро-Уілка, $з$ визначенням середнього арифметинчного (М) і стандартного відхилення (S). Для порівняння груп використовували критерії Мана-Уїтні, або U-критерій. При широкому порівнянні використовували метод ANOVA. Критичний рівень значущості $p$ у всіх розрахунках визначено як 0,05.

Результати досліджень та їх обговорення. При обробці даних виявлено збільшення часу операційного втручання. Загалом середній час опера-

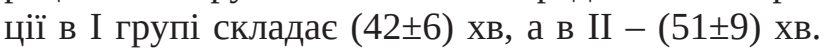

Збільшення часу на 17 \% не приводить до будьякого статистично значущого збільшення ускладнень під час чи після операції, а також не збільшує час відновлення хворого і сумарний час перебування у стаціонарі. Обидва показники знаходять в межах контрольованого наркозу та не перевищують 2 год у маргінальних значеннях, що не збільшує ризик респіраторних ускладнень після операції за шкалою ARISCAT. Сумарна крововтрата у мілілітрах не відрізнялась більш ніж на 5 мл і також не мала статистичних наслідків. Рівень креатиніну сироватки на всіх етапах не перевищував 2 мг/дл, що не збільшувало ризик серцево-судинних подій. Показники, які відповідали за рівень хірургічної стрес-відповіді, контролювали на різних етапах лікування, включно операційний етап. Для курації хворих використовували протоколи ERAS для усіх пацієнтів. Контроль насичення вуглеводами хворих достатньою мірою допоміг запобігти суб’єктивному дискомфорту, а рівень глікемії лабараторно не відрізнявся і не потребував корекції інсуліном. Рівень глікемії має досить високу інформативність у передбаченні хірургічної стресреакції (рис. 1).

За критерій розвитку артеріальної гіпотензії було прийнято зниження середнього артеріального тиску на 30 \% від початкового або нижче 80 мм рт. ст. у систолічній фазі чи девіацією сегмента ST на ЕКГ. Тактика купірування гіпотензії однакова у всіх випадках і полягала у збільшенні темпу інфузії, збільшенні кількості колоїдів чи додавання пресорів. Після збору і підрахунку даних суттєвої різниці між середнім систолічним і діастолічним тиском протягом операції, яка могла б вплинути на ризики ускладнень, не виявлено (рис. 2).

Час операції - один з найважливіших показників ефективності методу, збільшувався несуттєво і від- 
повідно не спричиняв збільшення рівня п/о ускладнень. У свою чергу, сумарний час наркозу, включно період безопераційного наркозу (інтубація-екстуба- ція) зріс і відповідно також незначно. Анестезіологічні ризики не збільшувались, відповідно, ускладнення, пов’язані з ними, не зростали (рис. 3).

\section{Рівень глюкози}

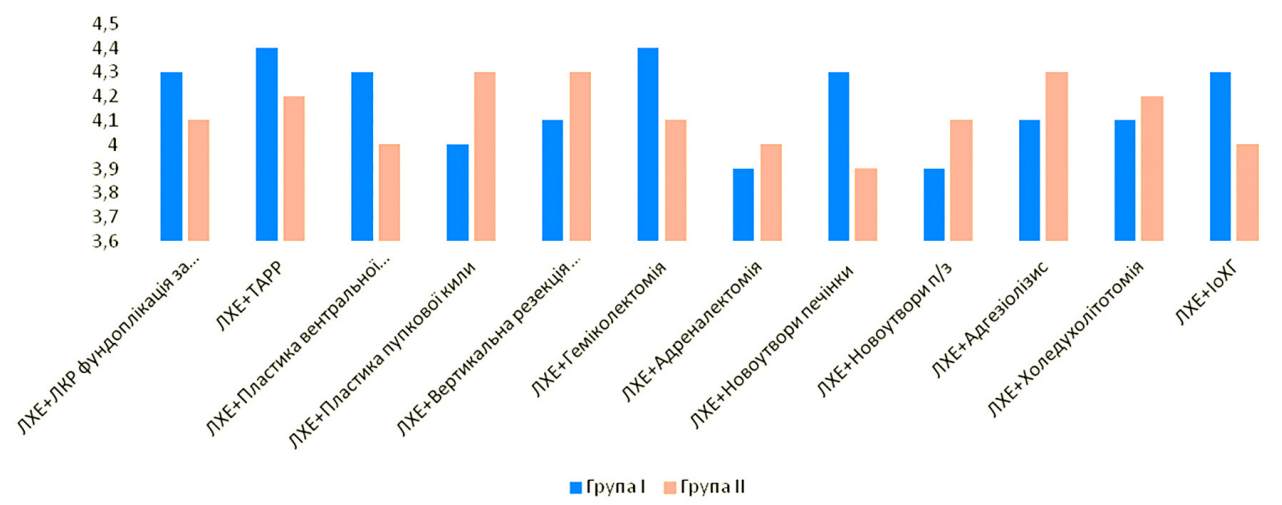

Рис. 1. Рівень глюкози у хворих I і II групах.

\section{Середній АТ під час операції}

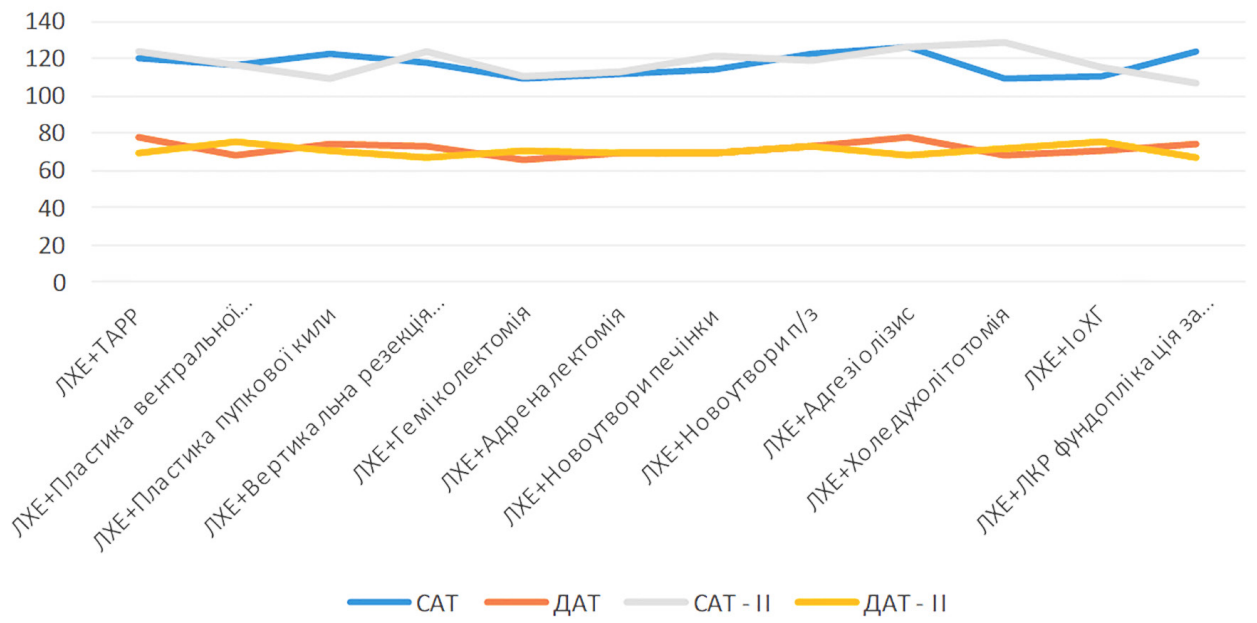

Рис. 2. Середній АТ під час операції.

\section{Загальний час операції. Група I}

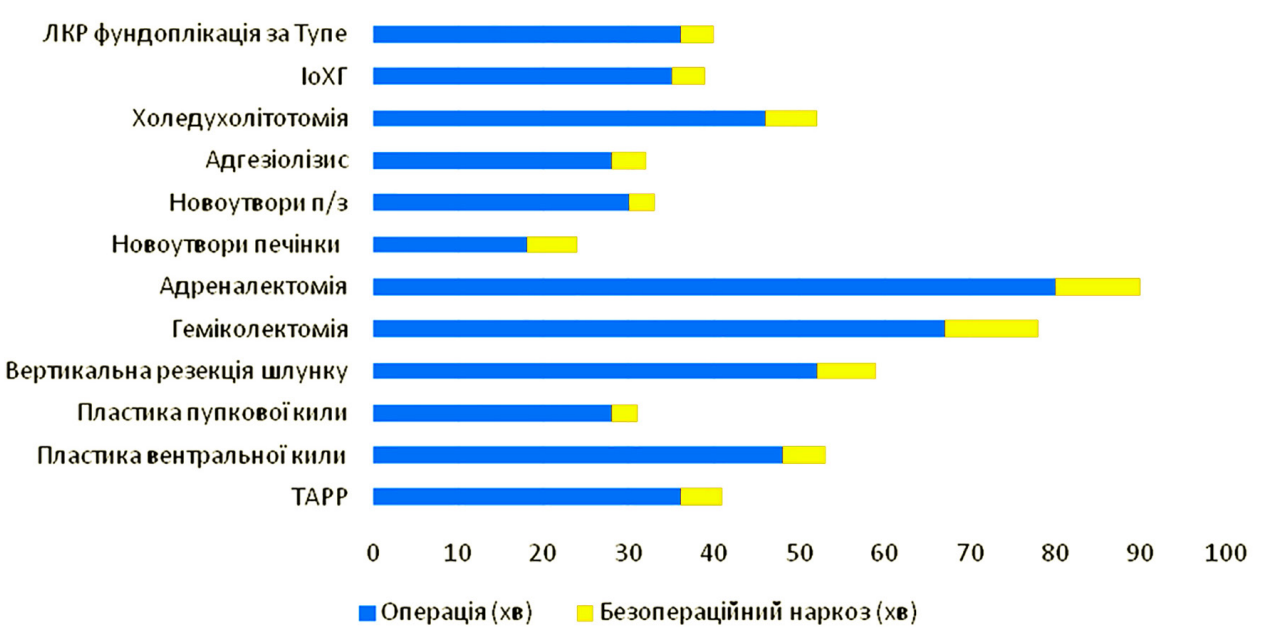

Рис. 3. Загальний час операції в I і II групах. 


\section{Загальний час операції. Група II}

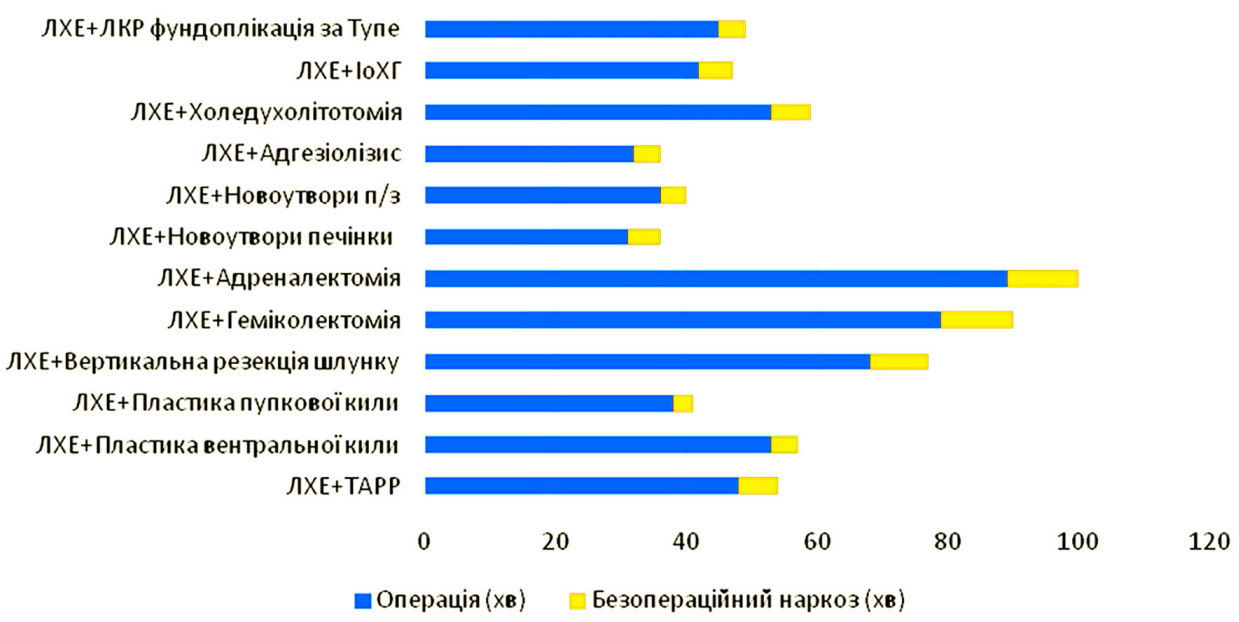

Рис. 3 (продовження). Загальний час операції в I і II групах.

Висновки. 1. Хірургічна стрес-відповідь - головна причини післяопераційних анестезіологічних ускладнень і летальності. Зменшення виразності стрес-відповіді завжди призводить до швидшої реконвалесценції.

2. Виконання симультанних операційних втручань із приводу ЖКХ та супутньої хірургічної патології органів черевної порожнини не призводить до збільшення основних показників хірургічної стресвідповіді та не збільшує періопераційні ризики.

3. Симультанні лапароскопічні операції -

\section{СПИСОК ЛІТЕРАТУРИ}

1. https://reference.medscape.com/refarticle-srch/175667-overview 2. Effects of indomethacin on endocrine responses and nitrogen loss after surgery / T. Asoh, C. Shirasaka, I. Uchido [et al.] // Ann. Surg. - 1987. - Vol. 206. 770-776.

3. Smith R. Depth of anesthesia with desflu-rane does not influence the endocrine-methabolic response to pelvic surgery / R. Smith, A. Kee, S. Barrat // Acta Anaesth. Scand. - 2008. Vol. 52. - P. 99-105.

4. Multimodal analgesia and intravenous nutrition preserves total body protein following major upper gastrointestinal surgery / B. Beilin, F. Martin, Y. Shavit // Reg. Anesth. Pain Med. - 2002. - Vol. 27. - P. 15-22.

5. Beilin B. Supression of natural killer cell activity by high-dose narcotic anesthesia in rats / B. Beilin, H. Bessler, E. Mayburd // Brain Behave Immun. - 1989. - Vol. 3. - P. 129-137.

6. Bent J. Effects of preemptive analgesia on pain and cytokine production in the postoperative period / J. Bent, J. Paterson, K. Mashiter // Anesthesiology. - 2003. - Vol. 98. - P. 151-155. 7. Bromage P. Effects of high-dose fentanyl anaesthesia on the established metabolic and endocrine re-sponse to surgery / P. Bromage, H. Shibata // Anaesthesia. - 1978. - Vol. 39. - P. 19-23.

8. Influence of prolonged epidural block-ade on blood sugar and cortisol responses to operation upon the upper part of the abdomen and thorax // Surg.Gynaecol. Obstetr. - 1971. - Vol. 21. - P. 330-335. ефективний і безпечний спосіб лікування, що має низку позитивних моментів не лише з боку об'єктивних числових показників, а й суб'єктивно для кожного пацієнта $є$ привабливішим.

4. Метод встановлення портів та забезпечення ергономіки, розроблений на базі Волинської обласної клінічної лікарні у відділенні інвазивних методів діагностики та лікування, забезпечує несуттєву, статистично незначущу відмінність основних показників із показниками групи хворих, що перенесли лише одну операцію.

9. Continuous epidural blockade arrests of postoperative decrease in muscle protein fractional synthetic rate in surgical patients / D. Halliday, J. Cassuto, P. Nellgard, L. Stage // Anesthesiology. 1997. - Vol. 86. - P. 1033-1040.

10. Desborough J. The role of neuroinflammation and neuroimmune activation in persistent pain / J. Desborough, G. Hall // Pain. - 2001. - Vol. 90. - P. 1-6.

11. Desborough J. Modification of the hormonal and metabolic response to surgery by narcotics and general anes-thesia / J. Desborough // Clin. Anaesthesiol. - 1989. - Vol. 3. - P. 317-334.

12. Garlick P. The stress response to trauma and surgery / P. Garlick, H. Burns, R. Palmer // Br. J. Anaesth. - 2000. Vol. 85. - P. 109-117.

13. Kehlet $\mathrm{H}$. The stress response to surgery: release mechanism and the role of pain relief / H. Kehlet // Acta Chir. Scand. - 2006. -Suppl. 55. - P. 22.

14. Kehlet H. Multimodal approach to control postoperative pathophysiology and rehabilitation / H. Kehlet // Br. J. Anaesth. -1997. - Vol. 78. - P. 606-617.

15. Kehlet H. Modification of responses to surgery by neural blockade: clinical implications / H. Kehlet, D. Wilmore. - In: M. Cousins, P. Bridenbaugh (eds) Neural blockade in clinical anesthesia and management of pain. Philadelphia, PA: Lippincott, 1998. - P. 129-175. 


\section{REFERENCES}

1. https://reference.medscape.com/refarticle-srch/175667-overview 2. Asoh, T., Shirasaka, C., Uchido, I., Baldini G., Bagry H., \& Carli, F. (1987). Effects of indomethacin on endocrine responses and nitrogen loss after surgery. Ann. Surg., 206, 770-776.

3. Smith, R., Kee, A., \& Barrat, S. (2008). Depth of anesthesia with desflu-rane does not influence the endocrine-methabolic response to pelvic surgery. Acta Anaesth. Scand., 52, 99-105.

4. Beilin, B., Martin, F., \& Shavit, Y. (2002). Multimodal analgesia and intravenous nutrition preserves total body protein following major upper gastrointestinal surgery. Reg. Anesth. Pain Med., 27, 15-22.

5. Beilin, B., Bessler,,H., \& Mayburd, E. (1989). Supression of natural killer cell activity by high-dose narcotic anesthesia in rats. Brain Behave Immun., 3, 129-137.

6. Bent, J., Paterson, J., \& Mashiter, K. (2003). Effects of preemptive analgesia on pain and cytokine production in the postoperative period. Anesthesiology, 98, 151-155.

7. Bromage, P., \& Shibata, H. (1978). Effects of high-dose fentanyl anaesthesia on the established metabolic and endocrine re-sponse to surgery. Anaesthesia, 39, 19-23.

8. (1971). Influence of prolonged epidural block-ade on blood sugar and cortisol responses to operation upon the upper part of the abdomen and thorax. Surg. Gynaecol. Obstetr. 21, 330-335. 9. Halliday, D., Cassuto, J., Nellgard, P., \& Stage, L. (1997). Continuous epidural blockade arrests of postoperative decrease in muscle protein fractional synthetic rate in surgical patients. Anesthesiology, 86, 1033-1040.

10. Desborough, J., \& Hall, G. (2001). The role of neuroinflammation and neuroimmune activation in persistent pain. Pain, 90, 1-6.

11. Desborough, J. (1989). Modification of the hormonal and metabolic response to surgery by narcotics and general anes-thesia. Clin. Anaesthesiol., 3, 317-334.

12. Garlick, P., Burns, H., \& Palmer, R. (2000). The stress response to trauma and surgery. Br. J. Anaesth., 85, 109-117.

13. Kehlet, H. (2006). The stress response to surgery: release mechanism and the role of pain relief. Acta Chir. Scand., (55), 22. 14. Kehlet, H. (1997). Multimodal approach to control postoperative pathophysiology and rehabilitation. Br. J. Anaesth., 78, 606-617.

15. Kehlet, H., \& Wilmore, D. (1998). Modification of responses to surgery by neural blockade: clinical implications. Neural blockade in clinical anesthesia and management of pain. Cousins, M., Bridenbaugh, P. (Eds.). Philadelphia, PA: Lippincott.

Отримано 03.01.2019

Електронна адреса для листування: voodoo.lsmu@gmail.com

I. YA. DZIUBANOVSKYI ${ }^{1}$, M. M. HALEI ${ }^{2}$, P. A. GASHCHISHYN², I. P. MARCHUK²

I. Horbachevsky Ternopil State Medical University ${ }^{1}$

Volyn Regional Clinical Hospital ${ }^{2}$

\title{
SAFETY AND EFFICIENCY OF SIMULTANEOUS LAPAROSCOPIC SURGERY IN TREATMENT OF GALLSTONE DISEASE AND SURGICAL COMORBIDITY
}

\begin{abstract}
The aim of the work: to find out the influence on physical health of the simultaneous laparoscopic operations in postoperative category of patients

Materials and Methods. Statistic data of 411 patients with gallstone disease with surgical comorbidity was used. For performance evaluation precise indicators were used, such as operative duration, hemorrhage volume, glycaemia, aldosterone and cortisol levels, oxygen blood saturation, creatinine and hemoglobin levels. Also Lee and ARISCAT scales were used. Results were used to make a database in Microsoft Office Excel 2010. Description of quantitative attributes was made based on the Shapiro-Wilk criterion, with the definition of the arithmetic mean (M) and standard deviation (S). Man-Whitney criteria or the U-criterion was used to compare the groups. For a wide comparison, the ANOVA method was used. The critical level of significance $\boldsymbol{p}$ in all calculations was detemined as 0.05 .

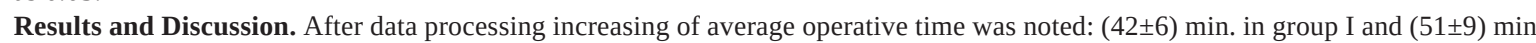
in group II. Regular monitoring the carbohydrates level in patients sufficiently helped to prevent subjective discomfort and weakness. Glycemic level didn't have much difference and did not require insulin correction. Criterion of development of arterial hypotension was determined as decrease of the middle blood pressure up to $30 \%$ from the initial or below $80 \mathrm{mmHg}$ in the systolic phase, or deviation of the ST segment on the ECG.
\end{abstract}

Key words: surgery; cholecystectomy; gallstone disease; laparoscopy; simultaneous; stress. 


\author{
И. Я. ДЗЮБАНОВСКИЙ ${ }^{1}$, Н. М. ГАЛЕЙ ${ }^{2}$ П. А. ГАЩИШИН ${ }^{2}$, И. П. МАРЧУК²
}

ГВУз “Тернопольский государственный медицинский университет имени И. Я. Горбачевского МОЗ Украины" Волынская областная клиническая больница ${ }^{2}$

\title{
БЕЗОПАСНОСТЬ И ЭФФЕКТИВНОСТЬ СИМУЛЬТАННЫХ .ЛАПАРОСКОПИЧЕСКИХ ВМЕШАТЕЛЬСТВ ПРИ ЛЕЧЕНИИ ЖЕЛЧНОКАМЕННОЙ БОЛЕЗНИ И СОПУТСТВУЮЩЕЙ ХИРУРГИЧЕСКОЙ ПАТОЛОГИИ ОРГАНОВ БРЮННОЙ ПОЛОСТИ
}

\begin{abstract}
Цель работы: исследовать влияние симультанных лапароскопических операций на физическое состояние послеоперационного больного.

Материалы и методы. В работе представлено статистические даные относительно лечения 411 больных ЖКБ и сопутствующей хирургической патологией. Для оценивания использовали чёткие числовые показатели: длительность операции, объём кровопотери, уровень гликемии, уровень кортизола и альдостерона, сатурация кислородом крови, уровень гемоглобина, креатинина. Оценивали по шкале Lee и ARISCAT. Полученые результаты вносили в базу данных Microsoft Office Excel 2010, описание количественных признаков на основе критерия Шапиро-Уилка с опредилением среднего арифметического (М) и стандартного отклонения (S). Для сравнения групп использовали критерий Манна-Уитни или U-критерий. При широком сравнении использовался метод ANOVA. Критический уровень значимости $p$ во всех расчётах определён как 0,05.

Результаты исследований и их обсуждение. При оброботке данных в первую очередь было выявлено увеличение време-

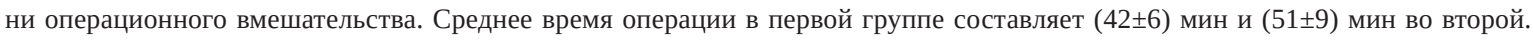
Контроль насыщения углеводами больных в достаточной степени помог избежать субъективного дискомфорта, а уровень гликемии лабараторно не отличался и не нуждался в коррекции инсулином. За критерий развития артериальной гипотензии было принято значение среднего артериального давления на 30 \% от начального или же ниже 80 мм рт. ст. в систолической фазе или девиацией сегмента ST на ЭКГ.
\end{abstract}

Ключевые слова: хирургия; холецистэктомия; желчекаменная болезнь; лапароскопия; симультанные вмешательства; стресс. 